\title{
Role of Multicultural Identity in Landscape Perception and Methodological Possibilities of Its Interdisciplinary Analysis
}

\author{
Jūratė Kamičaitytè ${ }^{1}$, Indrè Gražulevičiūtė-Vilenišké ${ }^{1}$, Sébastien Gadal ${ }^{2,3}$ \\ ${ }^{1}$ Kaunas University of Technology, Lithuania, ${ }^{2}$ University of Aix-Marseille, France, \\ ${ }^{3}$ North-Eastern Federal University, Russian Federation
}

\begin{abstract}
The paper presents the overview and comparative analysis of landscape cross-cultural and subcultural perception research methodologies in order to develop hypothetical methodological framework of interdisciplinary evaluation of cultural differences in landscape perception. The landscape research methods used for the analysis of impact of socio-cultural factors on landscape perception can be classified as mix of psychophysical and cognitive approach and are mostly based on the statistical analysis of the results of sociological research. Drawing the research closer to the relational concept, we propose the hypothetical methodological scheme of interdisciplinary evaluation of cultural differences in landscape perception that integrates landscape research with the knowledge of cultural studies, quantitative sociology (statistical analysis of the results of sociological research: factor analysis, component analysis, correlations, etc.), environmental psychology (cognitive mapping, Landscape Image Sketching Technique, landscape and environmental preferences, way finding, eyetracking, etc.), and geography (geomatic) (geographic information systems, remote sensing).

Keywords: landscape perception, identity, interdisciplinarity, multiculturalism
\end{abstract}

\section{Introduction}

Landscape as a social construct and process ongoing in time and space is constantly changing and due to that it can be considered as an objectively existing dynamic territorial system that is continually re-evaluated by different individuals (subjects). Regarding to ambiguous cultural, technological, social, etc. aspects of globalization, landscape perceivers/assessors are and will be the members of growing multicultural community. The preferences of each perceiver/assessor in terms of landscape are determined not only by psychological, individual, but also by socio-cultural factors, which are decisive for cultural identity. The relevance of the issue is also supported by European Landscape Convention [10] that defines landscape as an essential component of people's surroundings, an expression of the diversity of their shared cultural and natural heritage, and a foundation of their identity.

Cultural differences evaluating landscape are widely analysed in research articles $[6 ; 8 ; 15 ; 19 ; 28$; $32 ; 38 ; 40 ; 43 ; 49 ; 50]$, thesis and graduation works of different levels $[17 ; 27 ; 33 ; 39 ; 42]$, research projects, reports and guidelines $[22 ; 31$; 46]. The analysis of literature allows distinguishing several aspects of relevance of this research. Recent landscape ontology studies attempt to increase understanding and broaden knowledge about landscape as a social construct and objective reality (mapping the territory as integral natural-historical- cultural space) [22]. Regarding international tourism management, the increasing tourist flows, and diversity of visitors cause the challenges of landscape representation and interpretation for the visitors of different cultural contexts $[31 ; 33 ; 46]$. The arising new environments, that can be identified as multicultural spaces or, to say better, intercultural [52] spaces (for ex., office parks and buildings, indoor parks etc. that are used by the personnel of international corporations that employ people from different cultures) raise the questions, what are the environmental designs that are acceptable for the people of different cultures; how the multiculturalism/interculturalism is expressed in landscape design. Cultural literacy [52] in landscape design and management becomes of crucial importance as the landscape architect or the team of architects from one cultural context working in another strongly different cultural context nowadays is everyday reality. Another aspect related with multiculturalism and landscape architecture are the global migration and contemporary multicultural cities [1-4]. Such cities require public spaces acceptable and comfortable for their diverse population $[17 ; 34 ; 52 ; 54]$. Moreover, the public spaces honouring specific cultures or engaging the previously marginalized groups and both acceptable for general population are now a challenge of landscape design [53]. Sense of belonging to the 
place, creating the place attachment are very important in this context. This involves the search for distinguished aesthetics, cultural literacy, participation and reconciliation. The challenge of preserving, actualizing and interpreting valuable regional landscapes in the increasing multicultural society can be distinguished as well [41]. New and constantly developing international aesthetic language of contemporary landscape architecture needs consideration in the context of cultural literacy too. Different and sometimes radical trends, such as vast artificial colourful surfaces, the use of recycled materials and objects, minimalist spaces or overgrown ecological spaces with wild grasses can be accepted quite differently by the representatives of different cultures both in different cultural and multicultural contexts. This challenge can be further expanded to the search for the aesthetic language for the sustainable, biophilic landscape architecture in different cultural and multicultural contexts. It will be successful only if culturally acceptable.

Today's technological capacities of integration and analysis of huge amount of data allow to understand the influence of cultural differences on landscape perception, to evaluate it and to integrate it into landscape design and planning. Remote sensing approaches mapping land surfaces characterising the different landscapes and the footprints of the processes of territorialisation reflect the interaction of human culture, economics, development and planning policies, architecture and natural environment. The perception's cartographies of people in geographic information systems (GIS) merged with landscapes mapped by remote sensing allow to represent different landscape perceptions in regard of the objective reality.

Considering the above mentioned aspects the aim of the work is to formulate the methodological assumptions of landscape evaluation and modelling based on interdisciplinary approach (as the research object - landscape is the object of interest of many disciplines and it is complex and multi-layered), that will allow to identify the influence of different cultural backgrounds and social contexts on subjective perception and assessment of landscape, its preferences and mental image as well as to relate it with objective landscape indicators.

\section{Cultural factors influencing landscape perception}

Landscape perception depends on the subjective and objective aspects. The relational concept of landscape evaluation states that the result of landscape evaluation depends on the characteristics both of landscape (as an object) and observer (as a subject - society) as well as on relation of the subject and object [21]. It is necessary to note that in the field of landscape research in the above-mentioned interaction of landscape and its observer the role of the social and cultural aspects and sociocultural context are often overlooked; however,

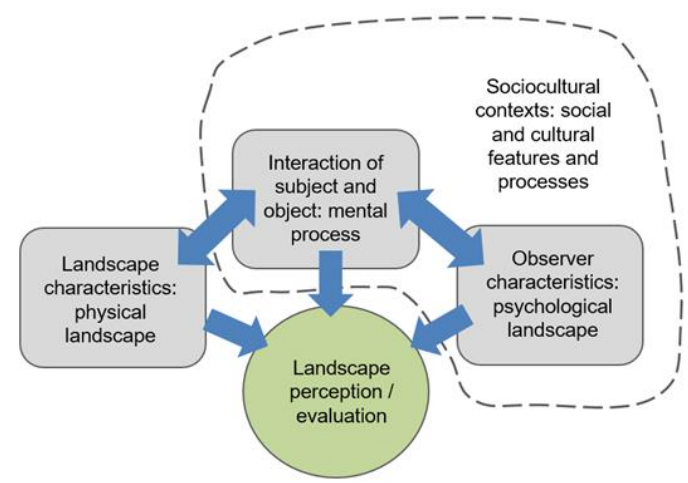

Fig. 1. The theoretical model of landscape perception/evaluation process

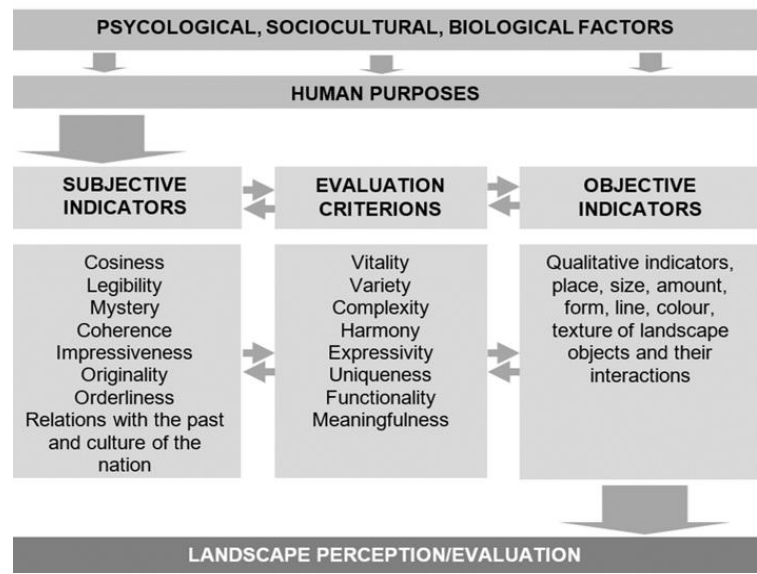

Fig. 2. The place of sociocultural factors in the theoretical framework of landscape perception/evaluation

this is not allowed in the multicultural landscape perception analysis (Fig.1).

The subject - people perceiving/evaluating landscape - are influenced by various factors and sociocultural among them (Fig. 2).

Many scientists state that though the perception and interpretation of landscape is an individual act, nevertheless it is strongly influenced by cultural factors that can explain some important aspects of human choices while evaluating the landscape [20; 29; 30; 48; 57]. For ex.: how people perceive categories of landscape according to the level and intensity of anthropogenization, particular places, landscape components, elements and relations among them, visual features, etc. The landscape observers also are influenced by the global (for ex., being a member of western culture), national (for ex., water meaning in Lithuanian culture) and local (for ex., development of topophilia values) cultural factors. This leads to the conclusion that cultural influence is a multi-layered phenomenon [20] as landscape itself.

Elaborating the concept of sociocultural factors, it can be stated that there is a vast array of them influencing landscape perception/evaluation: nationality, place of residence (urban or rural), politics, preparatory information, professional 
experience, daily accessibility to the landscape, familiarity with the area, economics, religion, social values/rules, belonging to a particular class of the society, etc. [18].

Human aesthetic responses occur in the three main levels: biophysiological, psychophysiological and intellectual or cultural $[5 ; 24]$; but do culture and sociodemographic factors really affect landscape evaluation process [26]? Though some research state that despite cultural differences people have similar preferences for specific landscapes, some cultural aspects, such as novelty, familiarity, living environment, education level do have impact on landscape evaluation and the issue is nevertheless worth deeper and more methodologically grounded analysis.

\section{Review of existing research methods for evaluating impact of cultural factors on landscape perception}

There are a lot of classifications of landscape research methods but the most common one classifies them into objective, subjective and relational (complex or integrated) according to the main dimensions of landscape perception (Fig. 1) [21;26]. Summing up the findings of Zube et al (1982) [56] and Terkenli (2001) [45] there can be identified four landscape research paradigms that can be classified according to objective, subjective or relational aspect: the expert paradigm, the psychophysical paradigm, the cognitive paradigm, and the experiential paradigm.

The expert paradigm is based on expert judgments of visual quality of landscapes while the opinion of non-experts is not considered. Evaluation of landscape quality depends on formal physical and visual characteristics of the landscape. It transforms landscapes into formal design parameters through the classification of landscapes biophysical features (geomorphological forms, vegetation, water, etc.) into characteristics which are considered to be important for landscape aesthetics i.e. forms, lines, textures, colours, and the relationships between these features, for ex., variety, vividness, unity, harmony. These methods include ecological and formal aesthetic models that are used in an objective manner. Visual aspects of landscape are analysed by morphological, aesthetic/visual, iconological, spectral/colour/thermal methods. Though this paradigm stresses the importance of objectivity of landscape research it is criticized for being incompatible with users' perceptions as the landscape is evaluated only by experts who perceive visual environment different to laity $[26 ; 45 ; 55]$.

Using the psychophysical paradigm landscape visual quality is evaluated by non-experts: the general public or special interest groups. The main assumption of this paradigm is that landscape as an object conditions the judgement of the observer without conscious thinking. Ranking and sorting are widely used techniques in visual assessments within this paradigm. It also can be called the perception-based approach where non-expert judgements are made over landscape stimuli and objective properties of landscape [26; 55]. Psychophysical methods integrate landscape evaluation as a whole and split it into objective landscape indicators as well. Therefore, they can be classified as complex methods as well.

Another perception-based approach is represented by the cognitive paradigm. It focuses on the analysis of reasons why people prefer particular landscapes, and states that landscape possesses the meaning and cognitive processes influence aesthetic judgements $[26 ; 55]$. Cognitive aspects of landscape are analysed by semiotic, ethnographic, hermeneutical, functionalstructuralist and other methods $[45 ; 55]$. The research main aim is to develop the theoretical basis. Evaluations of landscape visual quality are performed through the use of psychological scaling methods such as paired comparisons undertaken by human viewers (distribution of associative attributes, the theory of Ch. Osgood, 1957) or in accordance with behaviour patterns in the space (the theory of K. Lynch, 1960) $[7 ; 23 ; 55]$. However, this paradigm neglects the physical aspects of landscape (objective side) and emphasizes the subjective meanings of landscapes [26].

The experiential paradigm states that human experiences have impact on the landscape perceived value. Experiential aspects of landscape are analysed by behavioural, ethnographic, empirical (bioecological, economic, etc.), humanistic (pragmatist, phenomenological, etc.) methods [45; 55]. However, Taylor et al (1987) [44] and Kaymaz (2012) [26] recognize that it is more subjective than cognitive and psychophysical paradigms.

The landscape research methods used for the analysis of impact of socio-cultural factors on landscape perception can be classified as mix of psychophysical and cognitive approach. They are mostly based on the statistical analysis of the results of sociological research, though, some of them use different approaches such as Landscape Image Sketching Technique [49], qualitative interpretation of research results [40] or try to integrate linguistic aspect as additional to usual quantitative evaluation (interdisciplinary approach) [43]. Such studies usually require a set of landscape photographs, carefully prepared questionnaire and sample of respondents of different cultures (cross-cultural comparison of landscape preferences) or nationalities (sub-cultural comparison of landscape preferences) participating in the research. Ranking and sorting techniques are widely used in this type of landscape research (Table 1). 
Comparative analysis of the landscape research methods used for the analysis of impact of socio-cultural factors on landscape perception

\begin{tabular}{|c|c|c|c|c|c|c|}
\hline Reference & $\begin{array}{l}\text { Type of } \\
\text { research }\end{array}$ & $\begin{array}{c}\text { Research object and } \\
\text { result }\end{array}$ & Research techniques & 离 & : & 总 \\
\hline $\begin{array}{l}\text { Bruce Hull and } \\
\text { Reveli Grant, } \\
\text { (1989) [6] }\end{array}$ & $\begin{array}{l}\text { Sociological } \\
\text { survey }\end{array}$ & $\begin{array}{l}\text { Cross-cultural comparison } \\
\text { of landscape scenic } \\
\text { beauty evaluations: locals } \\
\text { and tourists gave different } \\
\text { evaluations to rural } \\
\text { landscapes in some } \\
\text { aspects }\end{array}$ & $\begin{array}{l}\text { Photo-questionnaire, } \\
\text { rating scales, statistical } \\
\text { analyses }\end{array}$ & + & - & - \\
\hline $\begin{array}{l}\text { Yang and Kapan } \\
(1990) \text { [50] }\end{array}$ & $\begin{array}{l}\text { Sociological } \\
\text { survey }\end{array}$ & $\begin{array}{l}\text { Analysis of landscape } \\
\text { style perception in a } \\
\text { cross-cultural context: } \\
\text { four landscape categories } \\
\text { were established common } \\
\text { for all groups of } \\
\text { respondents }\end{array}$ & $\begin{array}{l}\text { Photo-questionnaire, } \\
\text { rating scales, statistical } \\
\text { analyses }\end{array}$ & + & - & - \\
\hline $\begin{array}{l}\text { Herzog et al } \\
(2000) \text { [19] }\end{array}$ & $\begin{array}{l}\text { Sociological } \\
\text { survey }\end{array}$ & $\begin{array}{l}\text { Cross-cultural and } \\
\text { subcultural comparison of } \\
\text { landscape perception and } \\
\text { preferences: six } \\
\text { perceptual categories } \\
\text { were established with } \\
\text { quite high similarities for } \\
\text { all groups of respondents }\end{array}$ & $\begin{array}{l}\text { Photo-questionnaire, } \\
\text { rating scales, statistical } \\
\text { analyses }\end{array}$ & + & - & - \\
\hline $\begin{array}{l}\text { Le Lay et al } \\
(2008)[28]\end{array}$ & $\begin{array}{l}\text { Sociological } \\
\text { survey }\end{array}$ & $\begin{array}{lr}\text { Cross-cultural perception } \\
\text { of } & \text { riverscapes: } \\
\text { perceptions } & \text { differed } \\
\text { among countries } & \\
\end{array}$ & $\begin{array}{l}\text { Photo-questionnaire, } \\
\text { rating scales, statistical } \\
\text { analyses }\end{array}$ & + & - & - \\
\hline $\begin{array}{l}\text { Priego et al } \\
(2008)[40]\end{array}$ & $\begin{array}{l}\text { Sociological } \\
\text { survey }\end{array}$ & $\begin{array}{l}\text { Cross-cultural comparison } \\
\text { of perception and value of } \\
\text { nature in urban } \\
\text { landscapes: it was } \\
\text { established that people of } \\
\text { different socio-cultural } \\
\text { backgrounds use and } \\
\text { perceive nature in urban } \\
\text { areas in different ways }\end{array}$ & $\begin{array}{l}\text { Interviews of the selected } \\
\text { samples of the population } \\
\text { using standardised } \\
\text { questionnaires, qualitative } \\
\text { interpretation and } \\
\text { quantitative evaluation of } \\
\text { the research results }\end{array}$ & - & - & + \\
\hline $\begin{array}{l}\text { Schoenberg } \\
(2008)[43]\end{array}$ & $\begin{array}{l}\text { Sociological } \\
\text { survey }\end{array}$ & $\begin{array}{l}\text { Cross-cultural comparison } \\
\text { of landscape photo } \\
\text { perception: the answers } \\
\text { were strongly determined } \\
\text { by different cultural } \\
\text { backgrounds }\end{array}$ & $\begin{array}{l}\text { Photo-questionnaire, } \\
\text { combination of visual } \\
\text { perception and language }\end{array}$ & - & - & + \\
\hline Ueda (2014) [49] & $\begin{array}{l}\text { Sociological } \\
\text { survey }\end{array}$ & $\begin{array}{l}\text { Cross-cultural landscape } \\
\text { perception analysis using } \\
\text { Landscape } \\
\text { Sketching Image } \\
\text { there wechnique: } \\
\text { fundamental differences } \\
\text { in the ways of seeing the } \\
\text { landscape }\end{array}$ & $\begin{array}{l}\text { Drawing-questionnaire, } \\
\text { analysis of the drawings } \\
\text { in terms of represented } \\
\text { distance and viewing } \\
\text { angle, the position of the } \\
\text { stand-point, and the main } \\
\text { motifs of the sketches }\end{array}$ & - & - & + \\
\hline $\begin{array}{l}\text { Matijošaitienè et } \\
\text { al (2014) [32] }\end{array}$ & $\begin{array}{l}\text { Sociological } \\
\text { survey }\end{array}$ & $\begin{array}{l}\text { Cross-cultural comparison } \\
\text { of road landscape } \\
\text { perception: the research } \\
\text { results showed the } \\
\text { significant differences in } \\
\text { landscape perception } \\
\text { between the analysed } \\
\text { cultures }\end{array}$ & $\begin{array}{l}\text { Photo-questionnaire, } \\
\text { rating scales, statistical } \\
\text { analyses }\end{array}$ & + & - & - \\
\hline
\end{tabular}


Cultural differences evaluating landscape are widely analysed in the international scientific context $[6 ; 15 ; 19 ; 28 ; 38 ; 40 ; 43 ; 49 ; 50]$. Concerning the methodological aspect some of the research cases are worth to be analysed in detail.

In 1989 R. Bruce Hull and Grant R.B. Reveli performed cross-cultural comparison of landscape scenic beauty evaluations in Bali. Both similarities and differences were observed when comparing evaluations of rural landscapes made by locals and tourists. Multiple methods were used, including participant photography, rating scales, and a variety of statistical analyses. The research also suggested three methodological concerns which should be addressed in landscape studies: a concern for the participant's purpose for evaluating a landscape; a concern for the participant's familiarity with a landscape; and a concern for the criterion's appropriateness to all participants [6].

In 1990 Byoung-e Yang and Rachel Kaplan [50] performed analysis of landscape style perception in a cross-cultural context. The sample included three groups: Korean citizens, Korean students and Western tourists comparing influences of Western and non-Western culture on aesthetic judgement. The 40 scenes comprising the photo-questionnaire represented three landscape styles: Korean, Japanese and Western and four landscape qualities: lay-out of space, use of landscape plants, use of stones and rocks and use of water. Participants were asked to rate each scene in terms of their preference and degree of familiarity, using 5-point rating scale. The category identifying methods were used to obtain the results: the Smallest Space Analysis, nonmetric factor analysis and Hierarchical Cluster Analysis. After the results analysis four landscape categories emerged: Japanese/Water, Informal, Western/Formal and Korean/Rock for both Koreanbased and Western-based analyses [50].

One of the fundamental researches was made in 2000 by Thomas Herzog, Eugene J. Herbet and other scientists [19]. They compared perceptions and preferences for Australian natural landscapes of Australians and Americans. The Australian sample consisted of 384 participants of different age groups and American - of 250 students. The respondents evaluated 60 colour slides of natural environments in Australia how much they liked them using 5-point scale. Two types of statistical analysis were used: factor analysis that permitted comparison of landscape perceptual categories based on preference ratings by different cultures, correlations, and mean comparisons. Each of these analytical approaches provided different insights about cultural and subcultural landscape evaluation preferences. First the correlations among groups and subgroups based on setting scores were analysed. Then factor analysis was used to derive empirical groupings of the settings for the American and Australian samples and then the difference of the categories according to the mean preferences was analysed [19].

In 2008 Y.-F. Le Lay et al [28] analysed variations of cross-cultural perception of riverscapes. Human perception of riverscapes has been investigated with a photo-questionnaire submitted to 2250 students in ten countries, capturing reactions to 20 pictures in terms of naturalness, danger, aesthetics and need for improvement. The 10-point Visual Analog Scale (VAS) was used for quantifying the riverscape aesthetics. The Principal component analysis was performed on average scores per country per item. Perceptions differed among countries, reflecting different cultural contexts [28].

In 2008 C. Priego et al [40] analysed perception and value of nature in urban landscapes comprehended by people from different countries and cultures: Germany, Chile and Spain. The results of comparative analysis revealed that people of different socio-cultural backgrounds use and perceive nature in urban areas in different ways. The survey was conducted using standardised questionnaires and the stratified random probabilistic sampling technique in six study areas. The main aim was qualitatively examining the interaction between the nature and people through their perception of nature. Though the data were analysed in interpretive manner, it enabled the researchers to quantitatively explore the relationship between citizens and the urban nature [40].

In 2008 T. B. Schoenberg [43] analysed what differences and similarities can be found in landscape photo perception between groups of people from the American, Catalan and Russian cultures and how do people from different cultures, using their native languages, conceptualize and communicate about the landscape. The set of photographs included landscapes that are familiar and unfamiliar to all three cultures. Subjects were asked to write down what features they see in the order in which they see them. The purpose of analysis was to find differences and similarities in the answers both of individuals and of groups [43].

In $2014 \mathrm{H}$. Ueda [49] performed comparative landscape perception analysis in Japan and Germany using Landscape Image Sketching Technique (LIST). This research was different from the abovementioned ones according to its methodological approach, as to find out the cultural way of seeing landscapes empirically, a drawing method was used. The represented sketch showed the respondent's viewpoint and distance from the scene as well as the composition of figure and ground in the sketch. In addition to that, the sketch represented what the respondents look at and how they view the landscape. The obtained drawings were analysed in 
terms of represented distance and viewing angle, the position of the standpoint, and the main motifs of the sketches [49].

In 2017 C. Ordonez-Barona made a systematic review of the literature on how different ethnocultural groups value urban nature (forests). The 31 studies reviewed differed widely in their lines of inquiry, research methods, urban natural setting, and conceptualizations of ethno-cultural identity. The research approach used was mostly quantitative (for ex., survey), in seven cases qualitative and in five cases - mixed [38].

In Lithuania I. Matijošaitienè et al (2014) [32] also performed research in this field. There was compared the road landscape perception of the representatives of different cultures (Lithuanian, Armenian, Russian, Turkish, Arabian and African). The research results were obtained using sociological research methods: sociological survey based on semantic differential scale, and later on performing regression analysis and building a regression model of the hedonomic road landscape for each culture.

Though there are many researches made in this field they still encounter some technological problems that diminish the objectivity of the research results. The problems are the following [26]: using of photographs and other landscape 3D modelling techniques does not represent all the features of the reality fully, in-situ research is time and finance consuming, using of restricted pairs of adjectives for the semantic differential analysis limits people possibilities to use different descriptions for the same preference judgment, this imposes the need for content analysis of non-restricted descriptive verbal material of the research, etc.

\section{Interdisciplinary approach in evaluation of landscape perception cultural differences and proposed hypothetical methodological scheme}

Why interdisciplinary approach? As the interdisciplinary research is characterized by the development of a shared problem formulation and a common methodological framework for the investigation of different themes or aspects of the research problem $[12 ; 22]$, the necessity of the interdisciplinary approach is presupposed by the characteristic features of the research which are the following: interrogation of the dominant structure of knowledge with the aim of transforming them, and development of a shared problem formulation and a common methodological framework. We state that interdisciplinary approach can help to solve the issue of disbalance of landscape evaluation subjectivity and objectivity and draw the research closer to relational concept that embraces physical and psychological landscape evaluation aspects, and mental process of landscape perception. In general, the problems of landscape valuation are solved by philosophy, sociology, environmental psychology, geography, ecology, etc. Every field has its own attitude and methods of landscape research [55]. So, the first question is: what methods and disciplines can be integrated as landscape is the object of interest of many disciplines? And, the second question is how to integrate the methods and knowledge from different research domains for common aim of implementation of relational concept in landscape evaluation, and specifically - revealing of cultural differences in landscape perception and evaluation?

Answering to the first question we state that knowledge of sociology, cultural studies, environmental psychology, and geography could be integrated together with the field of landscape research here as the research object will be the landscape itself (objective aspect) and how people perceive and understand it (subjective aspect), and why they make particular preference judgements (relational aspect) (Fig. 3).

Landscape research in this model encompasses the traditional landscape analysis and modelling techniques but is not limited to them and may include biological (evolutionary), cultural and mixed landscape aesthetic theories [37], which can help integrating landscape research with environmental and evolutionary psychology and probably trace some cultural differences in landscape perception. Landscape visual characterization [37] and landscape aesthetic categories [36] are attributed to landscape research sphere as well.

The methods and techniques that can be used from the field of sociology are already widely described in the second chapter. Many existing research techniques are mostly based on the statistical analysis of the results of sociological research that help to reveal categories of visual stimuli or perceived landscape categories according to the preferences of the observers. The outcomes are evaluated in terms of the most and least preferred scenes, preference predictors (for ex., coherence, diversity, naturalness, etc.), correlations between preferences and predictors, content analysis of preferred environments or comparison of different landscape characteristics [26].

Regarding the importance of cultural literacy [52] in the context of multicultural landscape perception research, cultural studies are distinguished as a separate field in our model. Different disciplines and approaches ranging from sociology and psychology to management can be employed for the understanding of sociocultural context. For example, the field of evolutionary psychology dealing with human internal mechanisms as the adaptations that helped our ancestors to get around the world, survive and 


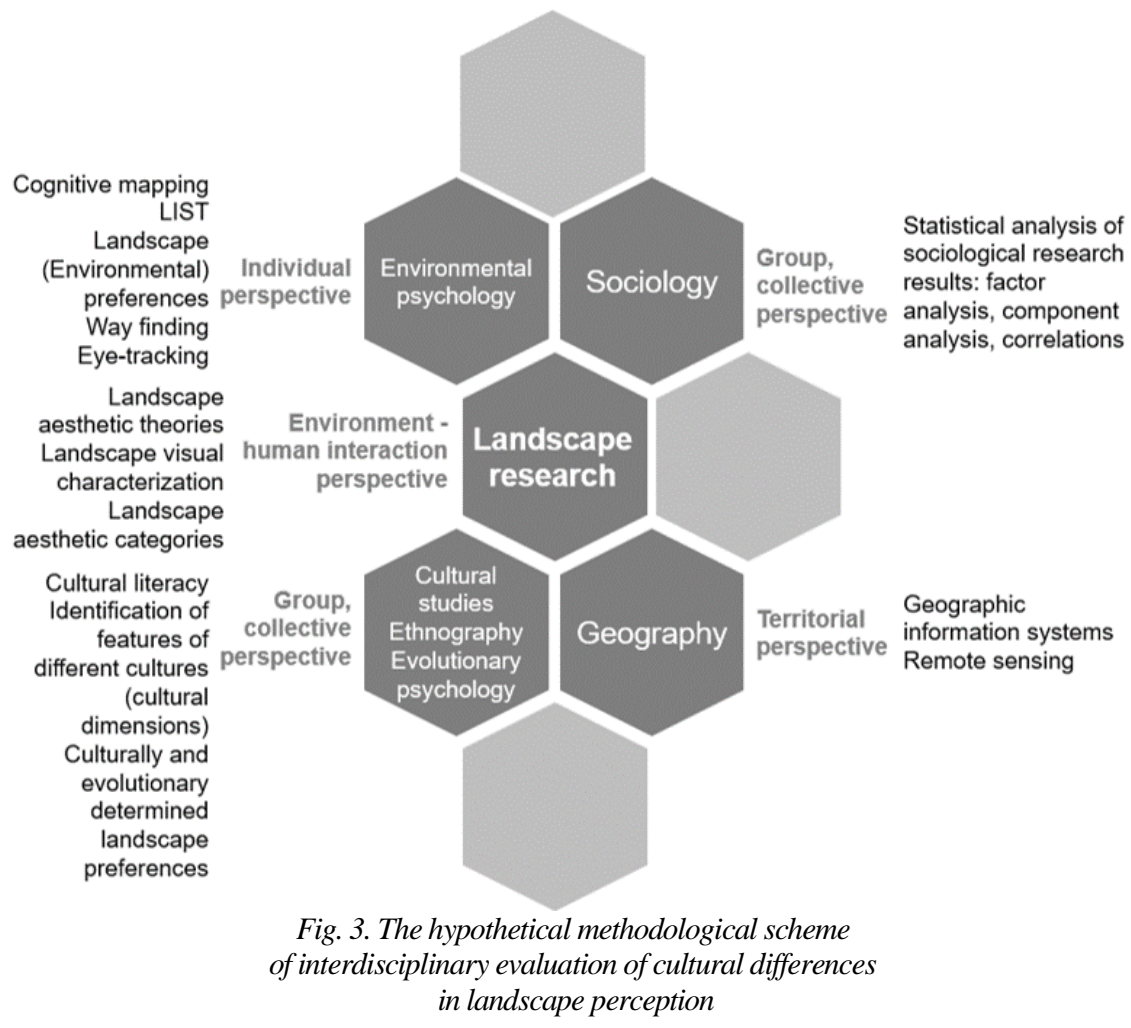

reproduce [11], can help understanding, why different landscapes are preferred by different cultures and what are the common landscape preferences shared by different cultures and why. The seven dimensions of cultures distinguished by C. Hampden - Turner and F. Trompenaars [16] can be a helpful tool in the multicultural landscape perception analysis if linked with particular landscape characteristics or environment formation concepts. Distinguished dimensions are presented in a form of dilemmas and include: achievement vs. ascription; individualism vs. communitarianism, internal vs. external; neutral vs. emotional; specific vs. diffuse; sequential vs. synchronous; universalism vs. particularism [16; 25; 47].

Environmental psychology is the branch of psychology which deals with relationships between physical environment and human behaviour (relational aspect). It is a multidisciplinary field where perception of the environment is a fundamental subject. Environmental perception research includes topics such as cognitive mapping, landscape (environmental) preferences, way finding, etc. [26]. Considering the analysed landscape research methods used for the analysis of impact of socio-cultural factors on landscape perception we can distinguish the research of H. Ueda (2014) [49] based on Landscape Image Sketching Technique and the way of mental maps construction developed by K. Lynch (1960) that allow to clear out the differences in landscape representation influenced by socio-cultural factors avoiding limitations of prevailing techniques of sociological research as well as are relevant to strengthen the relational aspect of the research.
Aiming at the more objective research results, the conceptual understanding of landscape can be analysed using geomatic approaches based on the geographic information systems and remote sensing of landscapes in geography [22; 51]. Geographic information systems that encompass psychological values derived from the visual landscape could be helpful for integration and analysis of the research results [20]. Remote sensing of landscapes would let us to recognise the landscape categories characterising the territories: the environments as the biogeographical distributions of the species, the types of "natural" landscapes, the structures of the geographic space, the types and forms of anthropogenization. The remote sensing is one of the key-approaches for building complex landscape indicators describing spatially the socio-geographicphysical realities of the territories. The spatial indicators contribute to an objective analysis of the landscape determining the characteristics of landscape and classifying landscape units according to natural and cultural factors on different geographic level local, regional or global - according to the spatial resolution of the sensors and image processing implemented. The impacts of the Earth observation data used define the level and accuracy of recognition of the landscape units $[13 ; 14]$ and territorial structures. The spatial indicators constitute a key-support for the analysis of the landscapes through the territorial structures showing the influence of the culture and religion on the land organisation [35]. They are also the spatial footprint of the territorialisation processes as the spatial 
structures of the geographic space and the territorial organisation. Their construction itself depends on the structure of the landscape studied by remote sensing resulting more or less from the complex interactions between space, nature, culture, economy, politics, conceptions and perceptions of landscapes and territories.

An objective way to measure people's observation of landscapes is also provided by eyemovement tracking. This technique allows the recording of the velocity and direction of eye movements (saccades) and the position and duration of fixations while observing images. Eye-tracking measurements are used in the field of environmental psychology, geography, cartography, and landscape science [9].

\section{Conclusions}

1. Socio-cultural factors, that are decisive for cultural identity and socio-cultural background, together with biological and psychological factors influence landscape perception and evaluation. They are subjective aspect of landscape evaluation that determine human aesthetic judgement and its reasons (objective indicators of landscape aesthetic visual quality). This triple nature (subjective, objective and relational) of landscape perception/evaluation process requires interdisciplinary methodological approach in landscape evaluation process for landscape cognition, planning and design purposes.

2. The history of the research of cross-cultural differences in landscape perception reaches the middle of 1980 [19], and since then the landscape research methods used for the analysis of impact of socio-cultural factors on landscape perception can be classified as mix of psychophysical and cognitive theoretical approaches. They are mostly based on the statistical analysis of the results of sociological research, though, some of them use different approaches such as Landscape Image Sketching Technique, qualitative interpretation of the research results or try to integrate linguistic aspect additionally to usual quantitative evaluation. Such studies usually require a set of landscape photographs, carefully prepared questionnaire and sample of respondents of different cultures (crosscultural comparison of landscape preferences) or nationalities (sub-cultural comparison of landscape preferences) participating in the research. Ranking, rating or sorting techniques are usually used in this type of the research.

3. Considering the existing technological problems of the research that diminish the objectivity of the research results and the need of reducing disbalance of landscape evaluation subjectivity and objectivity, and drawing the research closer to relational concept, we propose the hypothetical methodological scheme of interdisciplinary evaluation of cultural differences in landscape perception that integrates landscape research with cultural studies (cultural literacy, dimensions of cultures), knowledge of sociology (statistical analysis of the results of sociological research: factor analysis, component analysis, correlations, etc.), environmental psychology (cognitive mapping, LIST, landscape (environmental) preferences, way finding, eye-tracking, etc.), and geography (geographic information systems, remote sensing) as the research object is the landscape itself (objective aspect), how people perceive and understand it (subjective aspect), and why they make particular preference judgements (relational aspect).

\section{References}

1. Aboutorabi, M. Culture, Space, and Place: An İnquiry into the Urban Landscape of Multicultural Cities. Journal of Engineering and Architecture, 2018, Vol. 6, No. 2, p. 7-19.

2. Addas, A., Rishbeth, C. The Transnational Gulf City: Saudi and Migrant Values of Public Open Spaces in Jeddah. Landscape Research, 2018, Vol. 43, No. 7, p. 939-951.

3. Akguner, D. D. Multicultural and Secure Urban Areas: The Importance of Global and Local Connectedness [online 25.09.2019.]. https://www.berghoffoundation.org/fileadmin/redaktion/Publications/SecurityDialogueProject/Akguner.pdf

4. Amin, A. Ethnicity and the Multicultural City: Living with Diversity. Environment and Planning, 2002, Vol. 34, p. 959-980.

5. Bourassa, S. C. Toward a Theory of Landscape Aesthetics. Landscape and Urban Planning, 1988, Vol. 15, p. 241-252.

6. Bruce Hull, R., Reveli Grant, R. B. Cross-cultural Comparison of Landscape Scenic Beauty Evaluations: A Case Study in Bali. Journal of Environmental Psychology, 1989, Vol. 9, No. 3, p. 177-191.

7. Burgess, D., Patton, M., Georgiou, S., Matthews, D. Public Attitudes to Changing Landscapes: Implications for Biodiversity. Paper presented at the 11th BIOECON Conference, 21-22nd September 2009, Venice, Italy. 2009, p. $1-27$.

8. Byrne, J., Wolch J. Nature, Race, and Parks: Past Research and Future Directions for Geographic Research. Progress in Human Geography, 2009, Vol. 33, No. 6, p. 743-765.

9. Dupont, L., Antrop, M., Eetvelde, V. Eye-tracking Analysis in Landscape Perception Research: Influence of Photograph Properties and Landscape Characteristics. Landscape Research, 2014, Vol. 39, No. 4, p. 417-432.

10. European Landscape Convention [online 25.09.2019.]. https://rm.coe.int/1680080621

11. Evolutionary Psychology [online 25.09.2019.]. https://plato.stanford.edu/entries/evolutionary-psychology/ 
12. Frodeman, R., Klein, J. T., Mitcham, C. The Oxford Handbook of Interdisciplinarity. United Kingdom: Oxford University Press, 2012. 624 p.

13. Gadal, S. Automatic Zoning of Landscape Structures by Spatial Discontinuities Recognition. 94th Meeting of the Association of American geographers, Association of American geographers, March 1998, Boston, United States. 1998.

14. Gadal, S. Détection automatisée et tracé de frontières: cognitique, décision, influence des données. Géopoint 1998: Décision et Analyse Spatiale, Groupe DUPONT, May 1998, Avignon, France. 1998, p. 106-110.

15. Gnädinger, J., Solymosi, K., Paulini, I., Drexler, D. Perception of Cultural Landscapes by Different Ethnic Groups in Romania. In: Landscape Culture - Culturing Landscapes: The Differentiated Construction of Landscapes. Springer Fachmedien, 2015, Chapter: 6.3., p. 223-233.

16. Hampden - Turner, C., Trompenaars, F. Building Cross-Cultural Competence: How to Create Wealth from Conflicting Values. Chichester: J. Wiley \& Sons, 2000. 388 p.

17. He, Y. Multiculturalism in the Urban Landscape. Create a Better City with Multicultural Communities. Master thesis._New Zealand: Unitec Institute of Technology, 2015. 171 p.

18. Heijgen, E. Human Landscape Perception. Netherlands: Wageningen University, 2013. 144 p.

19. Herzog, T.R., Herbert, E.J., Kaplan, R., Crooks, C.L. Cultural and Developmental Comparisons of Landscape Perceptions and Preferences. Environment and Behavior, 2000, Vol. 32, No. 3, p. 323-346.

20. Jacobs, M. Psychology of the Visual Landscape. Exploring the Visual Landscape: Advances in Physiognomic Landscape Research in the Netherlands. Research in Urbanism Series (RiUS), 2011, Vol. 2, p. 41-54.

21. Kamičaitytè-Virbašienė, J. Kraštovaizdžio vizualinès kokybès reguliavimas kraštotvarkoje (Lietuvos pavyzdžiu). Ph.D. thesis. Kaunas: Technologija, 2003. 193 p.

22. Kamičaitytė-Virbašienè, J., Gadal, S. Development of Interdisciplinary Approach in Studies of Landscape Ontology. SGEM 2016: 3rd International multidisciplinary scientific conference on social sciences and arts, arts, performing arts, architecture and design, 24-31st August 2016, Albena, Bulgaria. 2016, p. 307-312.

23. Kamičaitytè-Virbašienė, J., Janušaitis, R. Some Methodical Aspects of Landscape Visual Quality Preferences Analysis. Environmental research, engineering and management, 2004, Vol. 3, No. 29, p. 51-61.

24. Kavaliauskas, P. A Sustainable Landscape Planning System and Landscape Ecology. Ekologija, 2007, Vol. 53, p. 4-9.

25. Kamičaitytė-Virbašienė, J., Gražulevičiūtė-Vileniškė, I. Principle of Dilemma Reconciliation and Its Use for Optimization of Globalization Influence in Kaunas Historic Center. Advanced Construction: proceedings of international conference, 13-14 November 2008, Kaunas, Lithuania. 2008, p. 60 - 70.

26. Kaymaz, I.C. Landscape Perception [online 26.11.2018.]. http://cdn.intechopen.com/pdfs/37563/ intech-landscape_perception.pdf

27. Kurtz, N. M. Multicultural Planning in Mid-sized Cities. Master thesis. Canada: University of Waterloo, 2014. 201 p.

28. Le Lay, Y.-F., Piégay, H., Gregory, K., Chin, A., Mutz, M., Dolédec, S., Elosegi, A., Wyzga, B., Zawiejska, J. Variations in Cross-cultural Perception of Riverscapes in Relation to In-channel Wood. Journal compilation (C) Royal Geographical Society (with The Institute of British Geographers), 2008, p. 268-287.

29. Lehman, D. R., Chiu, C.Y., Challer, M. Psychology and Culture. Annual Review of Psychology, 2004, Vol. 55, p. 689-714.

30. Lyons, E. Demographic Correlates of Landscape Preference. Environment \& Behavior, 1983, Vol. 15, No. 4, p. 487-511.

31. Mandy, Th. Moving Landscapes. National Parks and the Vietnamese Experience. Australia: NSW National Parks and Wildlife Service and Pluto Press, 2002. 134 p.

32. Matijošaitienė, I. Cultural Differences in Landscape Perception. Journal of Sustainable Architecture and Civil Engineering, 2014, Vol. 3, No. 8, p. 16-25.

33. Mohd-Shariff, M.K. A Cross-cultural Comparison of Visual Landscape Preferences for the Natural Environment. Ph.D. thesis._Colorado: Colorado State University, 1994. 160 p.

34. Mojanchevska, K. Accommodation of Cultural Diversity in Public Spaces: The case of Skopje (Macedonia). Ph.D. thesis. Rotterdam: Erasmus University Rotterdam, 2018. 417 p.

35. Niculescu, S., Gadal, S. Détection des structures spatiales afin de segmenter l'espace en unités paysagères. Application au plateau de Falticeni. Comunicari stiintifice de geografie, Revue de l'Académie des sciences Proceeding of the Science Academy, 2000, p. 156 - 162.

36. Nohl, W. Sustainable Landscape Use and Aesthetic Perception - Preliminary Reflections on Future Landscape Aesthetics. Landscape and Urban Planning, 2001, Vol. 54, p. 223-237.

37. Ode, A., Tveit, M. S., Fry, G. Capturing Landscape Visual Character Using Indicators: Touching Base with Landscape Aesthetic Theory. Landscape Research, 2008, Vol. 33, No. 1, p. 89-117.

38. Ordonez-Barona, C. How Different Ethno-cultural Groups Value Urban Forests and Its Implications for Managing Urban Nature in a Multicultural Landscape: A Systematic Review of the Literature. Urban Forestry \& Urban Greening, 2017, Vol. 26, p. 65-77.

39. Pisco, M. P. R. Transnational Urban Planning in the Multicultural City: An Analysis of Diversity Beyond Ethnoculturalism. Master thesis. Canada, Ontario, Toronto: York University, 2018. 82 p.

40. Priego, C., Breuste, H.-J., Rojas, J. Perception and Value of Nature in Urban Landscapes: A Comparative Analysis of Cities in Germany, Chile and Spain. Landscape Online, 2008, Vol. 7, p. 1-22.

41. Qvistrom, M. On Regional Landscapes in A Multicultural Society. Landscape Review, 2016, Vol. 9, No. 1, p. 193-195.

42. Sarraf, M. Spatiality of Multiculturalism. Ph.D. thesis._Stockholm: KTH Royal Institute of Technology School of Architecture and the Built Environment, 2015.212 p. 
43. Schoenberg, T.B. Differences and Similarities in Perception of Landscape Photographs between AmericanEnglish, Spanish-Catalan and Russian Speakers [online 27.02.2019.]. https://ubir.buffalo.edu/xmlui/handle/104 $77 / 43248$

44. Taylor, J. G., Zube, E.H., Sell, J.L. Landscape Assessment and Perception Research Methods. In: Methods in Environmental and Behavioral Research. Krieger Pub Co, 1987, p. 361-393.

45. Terkenli, T. S. Towards a Theory of the Landscape: the Aegean Landscape as a Cultural Image. Landscape and Urban Planning, 2001, Vol. 57, p. 197-208.

46. Thomas, M. E. A Multicultural Landscape: National Parks and the Macedonian Experience. Australia: NSW National Parks and Wildlife Service and Pluto Press, 2001. 65 p.

47. Trompenaars, F., Hampden - Turner, C. 21 Leaders for the $21^{\text {st }}$ Century. Great Britain: Capstone Publishing, 2001. $512 \mathrm{p}$.

48. Tuan, Y-F. Space and Place: The Perspective of Experience. Minneapolis, London: University of Minnesota Press, 2001.496 p.

49. Ueda, H. Landscape Perception in Japan and Germany. In: Shimizu H., Murayama A. (eds) Basic and Clinical Environmental Approaches in Landscape Planning. Urban and Landscape Perspectives, 2014, Vol. 17. Springer, Tokyo, p. 15-24.

50. Yang, B., Kapan, R. The Perception of Landscape Style: a Cross-cultural Comparison. Landscape and Urban Planning, 1990, Vol.19, p. 251-262.

51. Vogiatzakis, I.N., Marini, A., Careddu, M.B., Melis, M.T., Griffiths, G.H. The Use of GIS and Remote Sensing for Landscape Character Mapping: A Pilot Study from Sardinia. Paper presented at the 7th AGILE Conference on Geographic Information Science, 29 April-1 May 2004, Heraklion, Greece. 2004, p. 387-390.

52. Wood, Ph., Landry, Ch. The Intercultural City. Planning for Diversity Advantage. UK: Routledge, 2007. 382 p.

53. Yazdani, N., Lozanovska, M. Representation of Multiculturalism in Urban Green Spaces. A Review of Immigrants' Experiences in Australia. In: $U H P H_{-}$14: Landscapes and ecologies of urban and planning history. Deakin University, 2014, p. 851-864.

54. Yücesoy, E. U. Everyday Urban Public Space. Turkish Immigrant Women's Perspective. Ph.D. thesis._Amsterdam: Het Spinhuis Publishers, 2006. 222 p.

55. Zaleskienė, E., Kamičaitytè-Virbašienè, J., Gražulevičiūtè-Vileniškè, I. Aesthetic Aspects of Landscapes in the Rural-urban Interface Zones. Acta biologica universitatis Daugavpiliensis, 2013, Vol. 13, No 1, p. 173-188.

56. Zube, E.H., Sell, J.L., Taylor, L.G. Landscape Perception: Research, Application and Theory. Landscape and Urban Planning, 1982, Vol. 9, p. 1-33.

57. Zube, E. H. Environmental Psychology: Global Issues, and Local Landscape Research. Journal of Environmental Psychology, 1991, Vol. 11, p. 321-224.

AUTHORS:

Jūratė Kamičaitytė - PhD of Environmental Engineering and Land Management, Professor at the Faculty of Civil Engineering and Architecture of Kaunas University of Technology; Studentų St. 48, Kaunas LT-51367, Lithuania; e-mail: jurate.kamicaityte@ktu.lt

Indrė Gražulevičiūtė-Vileniškè - PhD of Environmental Engineering and Land Management, Associated Professor at the Faculty of Civil Engineering and Architecture of Kaunas University of Technology; Studenty St. 48, Kaunas LT-51367, Lithuania; e-mail: indre.grazuleviciute@ktu.lt

Sébastien Gadal - Habilitation of Geography (Habilitation à diriger des recherches), Professor of Geography in Geomatic and Spatial Analysis at Aix-Marseille Université, CNRS, ESPACE UMR 730029 Avenue Robert Schuman, 13621 Aix-en-Provence Cedex 1, France; Professor V.K.S. at North-Eastern Federal University, 670000 Yakutsk, Republic of Sakha, Russian Federation, e-mail: sebastien.gadal@univ-amu.fr

Kopsavilkums. Rakstā sniegta informācija par ainavu starpkultūru un subkultūru uztveres pētījumu metodolog̣iju. Aprakstītas ainavu izpētes metodes, kuras tiek izmantotas, analizējot sociāli kulturālo faktoru ietekmi uz ainavas uztveri. Analizētas kognitīvās pieejas, kas lielākoties balstītas uz socioloǵisko pêtījumu rezultātu statistisko analīzi. Rakstā tiek piedāvāta starpdisciplinārās novērtēšanas metodologijas shēma, kas ainavu izpēti integrē ar kvantitatīvās socioloǵijas zināšanām (sociolog̣isko pêtījumu rezultātu statistiskā analīze: faktoru analīze, komponentu analīze, korelācijas utt.), sasaisti ar vides psiholog̣iju (kognitīvā kartēšana, ainavas attēla skicēšanas tehnika, ainavas un vides izvēles, ceḷa atrašana, acu izsekošana utt.) un ǵeogrāfiju (g̊eogrāfiskās informācijas sistēmas, attālinātās izpētes). 